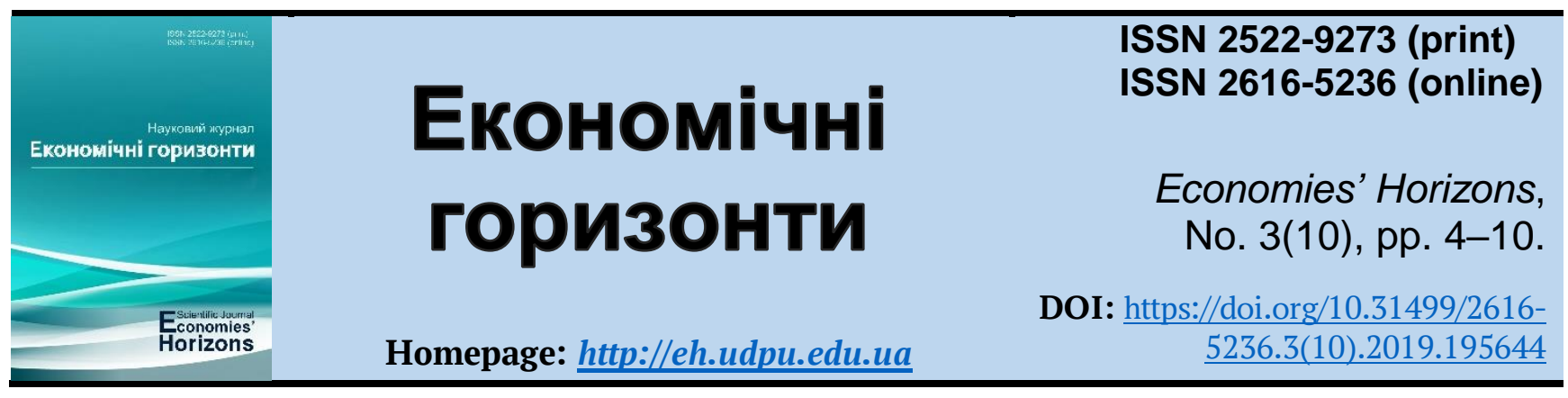

UDC 368.03:336

\title{
Management of financial results of insurance companies as an activator of the innovation-investment process
}

\author{
Yuliia M. Melnychuk ${ }^{1}$, Cand. Ec. Sc. \\ Oksana A. Vinnytska ${ }^{2}$, Cand. Ec. Sc., Associate Professor \\ Liudmyla A. Chvertko ${ }^{3}$, Cand. Ec. Sc., Associate Professor
}

Received: 7 July 2019

Melnychuk, Yu. M., Vinnytska, O. A. and Chvertko, L. A. (2019), "Management of financial results of insurance companies as an activator of the innovation-investment

Accepted: 10 August 2019 process", Economies' Horizons, no. 3(10), pp. 4-10, doi: https://doi.org/10.31499/26165236.3(10).2019.195644.

Abstract. This article is aimed at reviewing the process of managing financial information of insurance companies for the development of the innovation and investment process. The article considers scientific approaches to the problems on this issue. The purpose of the research. The purpose of the research is to determine the conceptual framework and basic principles of managing financial results of insurance companies. Methodology. The totality of research methods is a methodology for analyzing and organizing the main legislative acts and laws, namely the methods of generalization, comparison, chronology, analysis and generalization. Results. According to the results of the study, it was revealed that income from insurance activities, that is, all proceeds in favor of the insurer, related to insurance and reinsurance; income from investing and placing temporarily free funds (both own and funds of insurance reserves); other incomes, that is, those that do not belong to either insurance or investment income, but sometimes appear to the insurer in the course of its normal business activities. Practical meaning. The practical significance is that the issues of managing financial results of insurance companies are an activator of the innovation and investment process of the insurer and require practical application in the management process of the company. This will allow management to protect the company from unpredictable and perceived financial crises. Prospects for further research. The study of innovation and investment processes is relevant and necessary for insurance companies and require further research.

Keywords: innovations, investment process, financial management, financial results.

JEL Classification: G 11, G 22.

Number of references: 11; number of tables: 0; number of figures: $\mathbf{0}$; number of formulas: $\mathbf{0 .}$

\footnotetext{
${ }^{1}$ Pavlo Tychyna Uman State Pedagogical University; Associate Professor at the Department of Finance, Accounting and Economic Security; ORCID ID: https://orcid.org/0000-0003-4149-0205; e-mail: melnichykyuliya@ukr.net.

2 Pavlo Tychyna Uman State Pedagogical University; Associate Professor at the Department of Finance, Accounting and Economic Security; ORCID ID: https://orcid.org/0000-0001-6402-6451; e-mail: vinnytska.oksana@ukr.net.

${ }^{3}$ Pavlo Tychyna Uman State Pedagogical University; Associate Professor at the Department of Finance, Accounting and Economic Security; ORCID ID: https://orcid.org/0000-0003-2788-6991; e-mail: luda_um@ukr.net.
} 


\title{
Управління фінансовими результатами страхових компаній як активізатор інноваційно-інвестиційного процесу
}

\author{
Юлія Миколаївна Мельничук ${ }^{1}$, к. е. н. \\ Оксана Анатоліївна Вінницька ${ }^{2}$, к. е. н., доцент \\ Людмила Андріївна Чвертко ${ }^{3}$, к. е. н., доцент
}

Стаття надійшла: 7.07.2019 Стаття прийнята: 10.08.2019
Melnychuk Yu. M., Vinnytska O. A., Chvertko L. A. Management of financial results of insurance companies as an activator of the innovation-investment process. Економічні горизонти. 2019. № 3(10). C. 4-10. DOI: 10.31499/26165236.3(10).2019.195644.

Анотація. Представлене дослідження спрямоване на розгляд процесу управління фінансовою інформацією страхових компаній для розвитку інноваційно-інвестиційного процесу. У статті розглянуто наукові підходи до проблематики 3 даного питання. Мета дослідження. Метою наукового дослідження $\epsilon$ визначення концептуальних засад та основних принципів управління фінансовими результатами страхових компаній. Методологія. Сукупність методів дослідження становить методологію аналізу та організації основних законодавчих актів та законів, а саме методи узагальнення, порівняння, хронологізації, аналізу та узагальнення. Результати. За результатами дослідження виявлено, що доходи від страхової діяльності, тобто всі надходження на користь страховика, пов’язані з проведенням страхування і перестрахування; доходи від інвестування і розміщення тимчасово вільних коштів (як власних, так і коштів страхових резервів); інші доходи, тобто ті, які не належать ні до страхових, ні до інвестиційних доходів, але часом з'являються у страховика у процесі його звичайної господарської діяльності. Практичне значення. Практичне значення полягає в тому, що питання управління фінансовими результатами страхових компаній $\epsilon$ активізатором інноваційно-інвестиційного процесу страховика та потребує практичного застосування в управлінському процесі компанії. Це надасть змогу керівництву убезпечити компанію від непередбачуваних і передбачуваних фінансових криз. Перспективи подальших досліджень. Дослідження інноваційно-інвестиційних процесів $\epsilon$ актуальними і необхідними для страхових компаній і потребують подальших досліджень.

Ключові слова: інновації, інвестиційний процес, фінансове управління, фінансові результати.

Кількість джерел: 11; кількість таблиць: 0; кількість рисунків: 0; кількість формул: 0.

\section{Introduction.}

The development of individual regions of Ukraine in the innovation and investment direction is a key prerequisite for economic growth in the face of increasing global challenges and economic instability. The imple- mentation of the innovative model of economic transformation requires the use of the potential of all business entities in order to ensure structural and qualitative updating of production assets, modernization of the national economy, and the solution of important socio-

\footnotetext{
${ }^{1}$ Уманський держсавний педагогічний університет імені Павла Тичини; доцент кафедри фінансів, обліку та економічної безпеки; ідентифікатор ORCID: https://orcid.org/0000-0003-4149-0205; e-mail: melnichykyuliya@ukr.net.

${ }^{2}$ Уманський державний педагогічний університет імені Павла Тичини; доцент кафедри фінансів, обліку та економічної безпеки; ідентифікатор ORCID: https://orcid.org/0000-0001-6402-6451; e-mail: vinnytska.oksana@ukr.net.

${ }^{3}$ Уманський державний педагогічний університет імені Павла Тичини; доцент кафедри фінансів, обліку та економічної безпеки; ідентифікатор ORCID: https://orcid.org/0000-0003-2788-6991; e-mail: ludaum@ukr.net.
} 
economic problems. This fully applies to insurance organizations, which together form an important strategic segment and by providing insurance protection contribute to socio-economic stability in society, reduce the burden on the expenditure side of budgets of various levels, allowing to optimize the activities of economic entities through centralized financial funds resources, as well as accumulate financial resources for investing in the country's economy.

\section{Literature review.}

A comprehensive solution to diverse problems requires improving the systematic approach to managing financial results of insurance companies, developing the conceptual foundations of their financial management, taking into account modern realities. In the works of foreign authors, questions of theory and practice of managing financial results in a developed market economy are mainly covered by the example of firms. At the same time, the studies of economists N. Bilous (2011), O. Gamankova (2009), H. Kozoriz (2008), L. Lebedynska and L. Remnova (2006), A. Smolkyn (2011), Yu. Melnychuk, L. Chvertko, T. Korniienko, O. Vinnytska and O. Garmatiuk (2019) and many others.

\section{Methods.}

The totality of research methods is a methodology for analyzing and organizing the main legislative acts and laws, namely the methods of generalization, comparison, chronology, analysis and generalization.

\section{Research objectives.}

The purpose of this research study is to determine the conceptual framework and basic principles for managing the financial results of insurance companies.

The goal involves the sequential solution of the following tasks: study of a system of interconnected and focused strategic and tactical financial decisions in the financial management of the insurance company; revealing the dual nature of the financial activities of insurance companies in Ukraine; substantiation of the conceptual framework for managing the financial results of domestic insurance companies in the context of globalization.

\section{Results and discussions.}

The main feature of the activities of the insurance company is that, unlike the production sector, the insurer first accumulates funds from the insurer, creating the necessary insurance fund, and only then bears the costs associated with compensation for losses under the concluded insurance contracts. The effectiveness of the influence of insurance companies as a financial stabilizer on the socio-economic development of the regions largely depends on the perfection of methods for managing financial performance and their compliance with modern needs. To implement effective insurance protection for their customers, insurance companies must have sufficient financial resources and ensure their efficient placement. Moreover, the establishment of optimal ratios between individual sources of formation and use of financial resources of insurers is an important prerequisite for ensuring the continuity of the insurance process, the constant solvency of insurance companies and the stable financial results of their activities. At the same time, in parallel with providing quality insurance protection, it is necessary to increase the investment activity of insurers and provide it with an innovative direction in the context of fulfilling the priority tasks of the innovation and investment policy for sustainable development of the regions of Ukraine (Bazylevych and Bazylevych, 2008).

The dual nature of the financial activities of the insurer, both in carrying out insurance itself and in acting as an active investor, determines the specifics of the formation of its internal financial resources through three main types of income:

- income from insurance activities, that is, all proceeds in favor of the insurer related to insurance and reinsurance;

- income from investing and placing temporarily free funds (both own and funds of insurance reserves):

- other incomes, that is, those that do not belong to either insurance or investment income, but sometimes appear to the insurer in the course of its normal business activities. 
In the economic literature there is still no single point of view on the relationship between the concepts of "financial management" and "financial management" of insurance organizations, just as there is no single view on the relationship between the terms "management" and "management". The most balanced and scientifically substantiated in this context is the point of view of A. Smolkyn (2011), who believes that the scientific polemic on this issue is unfounded due to the objectively existing contradiction. So, the concept of "management", on the one hand, is broader than management, and on the other, it does not fully reflect the content of managerial activity, except management itself involves the organization of economic processes, its reproduction in the following cycles and improvement (Smolkyn, 2011).

H. Poliak (2006) identifies the concepts of "financial management" and "financial government" and believe that the literal translation of the English term "financial management" as financial government narrows its concepts to only one of the management methods. In his opinion, the definition of financial management is associated with the concept of a financial management mechanism at all hierarchical levels or the so-called financial mechanism, which is at the same time a component of the general economic mechanism and goes beyond its framework as an independent category. S. Ulina (2000) on the contrary, is trying to prove the difference between the terms "financial management" and "financial management". She believes that financial management as a term of American origin can be applied only when it comes to business, that is, to manage the financial and economic processes of a commercial organization. In her opinion, financial management is a broader concept than financial management, since it takes place in all economic formations, including the planned economy, and can be carried out both at the state level and at the level of commercial and non-profit organizations (Ulina, 2000).

The main factors that create favorable conditions for further deepening cooperation between banks and insurance companies in the process of direct and indirect impact on the investment market should include:

- availability of relevant regulatory legal acts; increased competition in the market of banking and insurance services;

- increasing solvency and the ability to attract significant savings of both potential investment resources of both banks and insurance companies of funds;

- the active development of mortgage and investment lending, which requires joint actions by banks and insurance companies to minimize financial risks;

- a high proportion of credit operations in bank assets, which also increases the risks of banking activities and requires a more active use of mechanisms for transferring part of the risks to insurers;

- increased requirements for the performance indicators of commercial banks (from the National Bank of Ukraine) and insurance companies (from the Ministry of Finance of Ukraine), which makes it mutually beneficial to invest these financial institutions in each other's shares and consolidate their long-term strategic ties.

Thus, the exceptional investment opportunities of insurers and their significant potential in the implementation of investment programs require a serious rethinking of the macroeconomic significance of insurance in the conditions of market transformations. After all, it is insurance that provides compensation for losses, creates a mechanism for their prevention and reduction, and thus actively influences the investment climate in the country and creates the conditions for a continuous reproduction process.

The main prerequisites for the interpretation of insurance as one of the effective tools for enhancing the innovation and investment processes in the region include (Lebedinska and Remnova, 2015):

- the existence of an inversion cycle and a closed layout of damage from the occurrence of insurance events, determines the availability of insurance-free funds as a source of 
investment in highly liquid investment instruments;

- the presence of equity of insurers, formed from retained earnings and additional contributions of the founders of the insurance company, which allows us to diversify its activities and increase the profitability of insurance operations themselves by generating additional income from the investment activities of the insurer;

- the indirect effect of insurance on the investment market by providing insurance coverage to investors, lenders, other participants in investment projects and programs, allows for the redistribution of part of investment risks and to increase capital investment in the real sector of the economy;

- the possibility of reinsurance of large investment risks by insurance companies and reinsurers, which allows to increase the level of reliability of insurance coverage of invested material and intellectual values, as well as to provide a more effective settlement of losses in the event of an insurance event.

Due to the special nature of insurance, its direct and indirect impact on the investment market, investment activities of insurance companies can be considered as a significant factor in the activation of investment processes in the country's economy. Given the latest trends in the intensive development of the Ukrainian insurance market, there is every reason to conclude that insurance companies have significant investment potential.

In order to intensify investment activity in the post-crisis period, domestic insurance companies must increase the level of capitalization of the insurance system and consolidate the domestic insurance business, introduce advanced management technologies, and increase the efficiency of insurance services and investment operations. At the same time, the undesirable consequences of globalization in the medium and long term can be avoided only by implementing a balanced policy of opening the insurance market. In this context, state regulation of all parts of the financial system, including insurance, should be based on the principle of dominance of national interests over various external and internal interests. As for such a component of the mechanism of financial management of insurers as legal, organizational and information support, it should be noted a number of important points arising from the essence of modern globalization processes:

- firstly, since globalization is a certain universal process of unification of types of consumption, organization and production management technologies, objectively there is a need to bring the legal regulation of financial processes in Ukraine in line with proven international standards. At the same time, the rethinking of the positive experience of legal support of investment, banking, and insurance activities, as well as the effective adaptation of Ukrainian legislation with international norms of economic and commercial behavior in the relevant segments of the world market, are of particular importance. Moreover, legal adaptation to the conditions of political, economic and monetary unions is an important prerequisite for effective regional integration of Ukraine into the European space;

- secondly, in the context of globalization, the organizational support of financial management should be formed taking into account the objective enlargement of economic entities as a result of reorganization, mergers and acquisitions, strengthening the worldwide role of large companies. Therefore, future changes in the organizational and economic structure of domestic insurance organizations under the influence of globalization are quite logical, the development of capital integration, the emergence of various diversified forms of doing business, the creation of their own transnational economic structures with global financial management. Accordingly, in connection with the alleged spread of integration corporate entities in the national economy, the role of corporate financial management will increase, in addition to common features for all business entities, it has certain features arising from the subject area of activity, environmental factors and the internal structure of a specific integrated organizational and economic structure; 
- thirdly, information support of the financial management of insurance activities in the third millennium will be objectively formed under the influence of scientific and technological achievements in the field of the latest information and communication systems. A new information basis is a prerequisite not only for effective integration into the global industrial, commercial and financial structures, but also for the achievement of a qualitatively new level of development of nonprimary and knowledge-intensive industries, which will ultimately determine the competitiveness of the national economy and its place in the world economy. It should be borne in mind that the current stage of globalization is characterized by the creation of conditions for the functioning of self-sufficient Internet economies in the global environment. Thanks to the unique application capabilities of the Internet and the rapid dynamics of the development of electronic commerce, global competition mechanisms are being formed that are not available for national regulation. And as practice shows, global Internet centers arise not only in the information leaders of the world, but also in countries that pursue a favorable investment policy.

In a changing environment with increasing cyclical development of transformational economies, it is necessary to rethink the principles of organizing financial management of insurers from the perspective of a comprehensive systematic approach to solving the problems of managing insurance organizations, taking into account the timely diagnosis of modern transformations, adequate assessment of factors and tools for the development of the insurance field, determination of objective determinants and modern vectors of development of insurance activity in a global environment, providing transport rent STI conditions of financial and economic activity of the insurance organizations in parallel with the constant monitoring of the implementation of the main results of their activities in the context of the operation of objective economic laws and regularities of the development of insurance business under the influence of globalization (Melnychuk, Chvertko, Korniienko, Vinnytska and Garmatiuk, 2019). At the same time, it is necessary to integrate the mutual influence on the financial performance of domestic insurance companies of modern macroeconomic theories of the stability of economic systems, regional integrity, marginal cost and harmonization of economic interests. In this case, it is necessary to proceed from the above expanded interpretation of the financial management of insurers as a system of interconnected and focused strategic and tactical decisions aimed at ensuring the rationalization of cash flows and the optimal combination of the interests of the state, industries, regions and individual insurance companies in the formation, distribution and use of financial resources for implementation core (insurance) activities and non-core (financial and investment activities).

\section{Conclusions.}

In a market economy, all business entities (both sectoral and territorial) should have full financial freedom. Only in conditions of free economic relations, economic entities achieve their highest efficiency (Melnychuk, Chyrva, Chvertko, Chyrva and Berbets, 2019). This approach necessitates integrated financial management in the insurance sector both at the national level and at the level of individual insurers. In our opinion, the criterion for successful insurance management in general and financial management, in particular, is the longterm effectiveness of the operation of the management object, which is reflected at the micro level in the growth of profitability of insurance operations, the intensification of investment activities of insurance companies, ensuring their financial stability and reducing insurance risks. At the same time, the stability of the financial management system should be determined by its ability to return to its original state and ensure further solvency of the insurance organization after exposure to negative factors, the most essential of which is the need to pay significant amounts of insurance indemnities in the event of an insurance event.

Conversely, at the macro level, evidence 
of the effectiveness of management decisions is an increase in the share of insurance premiums in the country's GDP, an increase in the capacity of the domestic insurance market, the concentration and centralization of a sufficient amount of "long" financial resources in the insurance sector and their investment in priority areas that ensure the innovative development of individual regions and national economy as a whole. In the plane of the aforementioned, in order to make fuller use of the existing investment potential of insurance companies, it is necessary to stimulate by economic methods the allocation of their temporarily free capital to the implementation of national and regional investment programs, as well as improve the legislative regulation of the allocation of insur- ance reserves in construction, mortgages, agricultural development, industrial restructuring, energy supply, energy conservation etc., in the long term injective significantly increases strategic role and the possibility of insurers in dealing with important issues of regional economic policy. At the same time, the optimal combination of strategically thought out state regulation of the insurance market and selfregulatory market mechanisms for enhancing the investment activities of insurance companies is key in the face of increasing global challenges and economic instability, since it is associated with solving problems to overcome the economic crisis, stimulate economic growth and implement an innovative model of economic transformation.

\section{References}

Bazylevych, V. D. and Bazylevych, K. S. (2008), Strakhove dilo [Insurance business], 6th ed., Knowledge, Kyiv, Ukraine, $351 \mathrm{p}$.

Bilous, N. M. (2011), "Features of the financial potential of life insurance companies", Visnyk Natsionalnoho universytetu vodnoho hospodarstva ta pryrodokorystuvannya. Seriya "Ekonomika", vol. 2 (54), available at: http://nuwm.rv.ua/metods/asp/vek541.pdf (Accessed 18 June 2019).

Gamankova, O. O. (2009), Rynok strakhovykh posluh Ukrayiny: teoriya, metodolohiya, praktyka [The market of insurance services in Ukraine: theory, methodology, practice], KNEU, Kyiv, Ukraine, 283 p.

Kozoriz, H. H. (2008), "Problems of development of the insurance market of Ukraine", Rehionalna ekonomika, vol. 2, pp. 182-191.

Lebedynska, L. D. and Remnova, L. M. (2006), "Insurance as a factor in financial stabilization of the economy", Aktualni problemy ekonomiky, vol. 9, pp. 65-74.

Lebedynska, L. D. and Remnova, L. M. (2015), "The role of banks and insurance companies in enhancing investment processes in the Ukrainian economy”, Siveryanskyy litopys, vol. 6, pp. 203-206.

Melnychuk, Yu, Chvertko, L., Korniienko, T., Vinnytska, O. and Garmatiuk O. (2019), "Analysis of the factors influencing the market of insurance services in life insurance", TEM Journal, vol. 8, issue 1, pp. 201-206, doi: https://dx.doi.org/10.18421/TEM81-28.

Melnychuk, Yu. M., Chyrva, O. H., Chvertko, L. A., Chyrva, H.M. and Berbets V. V. (2019), "The role of management in the financial independence of the region", TEM Journal, vol. 8, issue 2, pp. 584-590, doi: https://dx.doi.org/10.18421/TEM82-35.

Poliak, H. B. (2006), Fynansovyi menedzhment [Financial management], UNITY-DANA, Moscow, Russia, $527 \mathrm{p}$.

Smolkyn, A. M. (2011), Menedzhment: osnovy orhanyzatsyy [Management: organization basics], INFRA-M, Moscow, Russia, 248 p.

Ulina, S. L. (2000), "Approaches to the formation of a financial management system in Russia”, Management in Russia and Abroad, vol.2, pp.97-104, available at: http://bigc.ru/publications/other/finmanagement/podhody $\mathrm{k}$ form system finmanag $\mathrm{v}$ russia.php (Accessed 18 June 2019).

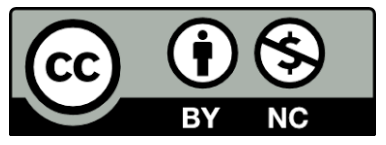

Цей твір ліцензовано на умовах Ліцензії Creative Commons «/з Зазначенням Aвторства - Некомерційна 4.0 Міжнародна» (CC BY-NC 4.0). This is an open access journal and all published articles are licensed under a Creative Commons "Attribution-NonCommercial 4.0 International" (CC BY-NC 4.0). 